Research.

\title{
THE EFFECT OF TRAINING, WORK STRESS AND WORK ABILITY ON WORK PERFORMANCE PT MUKTI MANDIRI LESTARI
}

\author{
Fitri Rezeki'); Rahmat Hidayat ${ }^{2)}$ \\ Department of Management. Universitas Pelita Bangsa \\ fitri_rezeki@pelitabangsa.ac.id ${ }^{1}$, rahmat_hidayat@pelitabangsa.ac.id ${ }^{2 *)}$ \\ * Corresponding author
}

Received: December 27, 2021 Accepted: December 30, 2021 Published: December 31, 2021

To cite this article: Rezeki, F.; Hidayat, R. (2021). The Effect of Training, Work Stress and Work Ability on Work Performance PT Mukti Mandiri Lestari. The Management Journal Of Binaniaga, 6 (2), 245-256 . doi: 10.33062/mjb.v6i2.481

\begin{abstract}
Human resources are very influential on work performances, because work performance is one of requirement, that have tobe owned by employees in order to produce good performances, and to achieve company goals. If the goal has been achieved, the employee will get an achievement from the company. This research aims to examine, verify and obtain results on how the influence of training, job stress and work ability on work performance. The results of this research indicated three things: (1) there is a positive and significant influence on the training of PT. Mukti mandiri Lestari. (2) there is a positive and significant effect on the work stress variable of PT Mukti Mandiri Lestari. (3) and there is a positive and significant effect on work ability.
\end{abstract}

\section{Keywords: Training, Work Stress, Work Ability, Work Performance}

\section{Background}

\section{INTRODUCTION}

In this era of globalization, human resources within the company are very important because they are needed to develop the company. If a company does not have human resources, the company will certainly fail and this goal will not be achieved. Because human resources are the key to determining the success of an organization in a company to produce goods or services. So that an employee who has human resources have to develop his/her abilities.

Human resources are very influential on work performance because work performance is one that must be owned by employees in order to produce good performance to achieve company goals. If the goals have been achieved, employees will get achievements from the company. Achievement is one of the successes achieved by someone in carrying out their duties. Not achieving a goal makes a lack of effectiveness in the company, and the company will experience waste if the employees do not excel. And the success achieved cannot be separated from the help of others, for example helping spiritually and other assistance.

Salah satu faktor yang membuat prestasi kerja yaitu memperhatikan pelatihannya, karena pelatihan salah satu kewajiban yang sangat berpengaruh terhadap prestasi kerja. Apabila pegawai tidak memiliki kemampuan dalam bekerja pegawai tersebut tidak akan mendapatkan prestasi, maka dari itu pentingnya pelatihan dalam dunia kerja. Agar tercapainya tujuan perusahaan perlu adanya pengembangan pelatihan, dan bagian dari bagian dari pembelajaran untuk meningkatkan keterampilan pegawai tersebut. Pelatihan ialah bentuk rencana organisasi yang untuk memajukan keahlian kompetensi dan kepandaian pegawai. Penulis menyimpulkan pelatihan didalam suatu organisasi atau perusahaan itu penting agar tahu sejauh mana keahlian pegawai tersebut, jika pegawai merasa kurang dengan keahlian yang dimilikinya perlu adanya pengembangan pelatihan

Fitri Rezeki; Rahmat Hidayat. The Effect of Training, Work Stress and Work Ability on Work Performance PT Mukti Mandiri Lestari 
agar bias bekerja dengan maksimal.

One of the factors that make job performance is concerning in training, because training is one of the obligations that greatly affects work performance. If the employee does not have the ability to work, the employee will not get an achievement, therefore the importance of training in the world of work. In order to achieve the company's goals, it is necessary to develop training, and be part of the learning process to improve the skills of these employees. Training is a form of organizational plan to advance the skills, competencies and skills of employees. The author concludes that training within an organization or company is important in order to know the extent of the employee's expertise, if the employee feels lacking in the expertise he has, it is necessary to develop training so that he can work optimally.

Someone who is stressed, will experience tremendous pressure and mental disorders, that will affect work performance, so that he/she will experience stress if he/she does work excessively and lacks rest. If employees experience stress, employee performance will decrease and affect employees in the warehouse section of the company PT. Mukti Mandiri Lestari. Excessive work will also affect the health of the employee, it is better to work properly and not excessively. The environment and friendship cycle in the company can also trigger work stress, for example, if fellow employees do not have good friendships, it will certainly affect their work and decrease their achievements.

Work stress is a serious problem and often occurs to employees at work, where they work. Companies need to understand the stress experienced by all their employees and understand how to anticipate it. One example of work stress is the workload that is very much and piled up, especially the tasks given by superiors many times over. The author concludes that if employees feel stressed it will affect their mental and physical, which will affect their performance at work and decrease their production in the company PT. Mukti Mandiri Lestari in doing her job. And superiors should give jobs to their subordinates in accordance with the existing regulations in the company.

In improving work performance, it is necessary to have work ability, the ability that must be possessed by an employee, namely being able to work in the warehouse section so that there is no decline in PT. Mukti Mandiri Lestari. And able to work in any part, must have advantages in other jobs as well so that later if the employee is transferred, he can master the job.

A person's ability is very important because if someone does not have the ability to work, our work will be messy and will not succeed in achieving company goals which will result in stress at work. One's ability can be honed by learning and understanding it so that our abilities will increase little by little.

Table 1

Employee Work Achievement Results of PT. Mukti Mandiri Lestari

\begin{tabular}{|c|c|c|c|l|}
\hline \multicolumn{3}{|c|}{ Year of 2019 } & \multicolumn{2}{c|}{ Year of 2020 } \\
\hline Score & $\begin{array}{c}\text { Number of } \\
\text { Employees }\end{array}$ & $\%$ & $\begin{array}{c}\text { Number of } \\
\text { Employees }\end{array}$ & $\%$ \\
\hline P1 & 15 & 21.43 & 10 & 14.29 \\
\hline P2 & 12 & 17.14 & 11 & 15.71 \\
\hline P3 & 20 & 28.57 & 19 & 27.14 \\
\hline P4 & 13 & 18.57 & 16 & 22.86 \\
\hline P5 & 10 & 14.29 & 14 & 20 \\
\hline Total & 70 & 100 & 70 & 100 \\
\hline
\end{tabular}

Source: PT. Mukti Mandiri Lestari.

According to the table, it can be seen, that the result of the inspection of the

Fitri Rezeki; Rahmat Hidayat. The Effect of Training, Work Stress and Work Abilityon Work 
execution of PT. Mukti Mandiri Lestari, Cikarang showed a decline in the last two years, which means that the consequence of the evaluation of the work execution showed a decrease in the worker execution award file for unique classes in 2019 there were 15 representatives who had the option of completing the unusual. models, while in 2020 there are only 10 individuals who meet the extraordinary steps.

\section{Formulation of the Problem}

Prestasi kerja adalah hal penting dalam meningkatkan suatu keberhasilan perusahaan. Oleh karena itu, perusahaan harus melakukan upaya dalam meningkatkan prestasi kerja. Dengan mengetahui faktor apa saja yang mempengaruhi prestasi kerja PT Mukti Mandiri Lestari faktor yang dapat dilihat dari pembahasan tersebut adalah training (X1), work stress (X2), work ability (X3) sebagai variabel bebas, dan Work Performance (Y) sebagai variabel terikat..

Work performance is important in increasing a company's success. Therefore, companies must make efforts to improve work performance. By knowing what factors affect the work performance of PT Mukti Mandiri Lestari, the factors that can be seen from the discussion are training (X1), work stress (X2), work ability (X3) as the independent variable, and Work Performance $(Y)$ as the dependent variable.

According to this, it can be formulated as follows:

1. Does training affect the work performance of PT. Mukti Mandiri Lestari?

2. Does Work Stress affect the Work Performance of PT. Mukti Mandiri Lestari?

3. Does Work Ability affect the Work Performance of PT. Mukti Mandiri Lestari?

As explained in the above formulation in this research, the authors want to know how influential Training is on Work Performance at PT Mukti Mandiri Lestari, Work Stress on Work Performance at PT Mukti Mandiri Lestari, Work Ability on Work Performance at PT Mukti Mandiri Lestari.

\section{LITERATURE REVIEW}

\section{Work Performance}

Work performance in a company is very important, because it will make employees more enthusiastic in carrying out their duties. If the employee works seriously and conduct his responsibilities well, he will definitely get achievements from the company for his abilities and success at work. The company needs an increase in employee performance so that all workers in the company PT. Mukti Mandiri Lestari can excel and be competent. So that later all employees have good quality workers.

Hasibuan (Rahmi \& Aziz, 2017) the work achievement of the success achieved in carrying out the burdens given to him/her such as tasks based on experience, time, etc. While Logor (2015:3) concludes that work performance is the result achieved by employees in conducting their duties based on knowledge, skills. The author concludes that work performance is the result of someone in carrying out their duties, serious and responsible employees will get the achievements given by the company. Employees who excel will motivate other employees as well to be able to work well and support each other so that there are no disputes between employees.

\section{Work Performance Indicators}

Hasibuan (Amelia Rahmi et all, 2017) indicators are needed to measure work performance, as follows:

a. Honesty. Be honest in carrying out his work and do not violate the existing regulations in the company, and comply with the agreement with his superiors

b. Responsibility. Obliged to bear all responsibilities given to him, for example, must carry out tasks assigned by superiors.

c. Experience. Knowledge based on experience, someone who has quite a lot of experience in a certain field will certainly get achievements from the company.

\section{Definition of Training}

Sulistiyani et al., 2017) that training is started by orientation, namely the process

Fitri Rezeki; Rahmat Hidayat. The Effect of Training, Work Stress and Work Ability on Work Performance PT Mukti Mandiri Lestari 
by which employees are given knowledge and information about employees. Meanwhile, Marwansyah (Hutahaean, 2020) Comprehensive activities to improve, acquire, and develop job competition in skills according to job level. In conclusion, training is very important for employees to make it easier to carry out their work properly and optimally. Every employee of course must conduct training first before getting to know the world of work so that when they get a work, that they will understand the basics of starting work.

\section{Training Indicators}

The training indicators according to Mangkunegara (Haposan Hutahaean, 2020) are as follows:

a. Type of training. Training is needed to improve employee performance for middle and lower levels.

b. Training objectives. The goal must be measurable and tangible, therefore the training organized aims to improve the skills of participants in order to achieve maximum performance.

c. Theory. The material can be in the form of discipline, work ethics and manuscripts

d. The method used. The method used is a training method with participatory techniques, namely, simulations, games and exercises in class.

e. Qualification of participants. Permanent employees and staff are employees who meet the requirements and receive recommendations from the leadership.

f. Coach qualification. The qualifications used must meet the requirements to provide training, must build motivation

g. Time. The process of action that takes place or a series of circumstances on work performance. With the training, employees are expected to carry out their duties properly in order to get achievements from the company.

\section{Work Stress}

Handoko (Sulistiyani et al., 2017) where conditions when tense will affect emotions, ways of thinking and conditions, which will produce excessive stress and consequently will interfere with the implementation of their duties. And Rivai (Sulistiyani et al., 2017) where the condition of employee tension in creating a physical imbalance will occur, which affects the condition and emotions. The conclusion is that employees at work must be in good body condition, healthy and not stressed. Because if employees experience problems at work, it will affect the tasks and work they are doing, and experience work stress.

\section{Work Stress Indicators}

According to Robbins (Miftakul Sulistiyani et al, 2017) suggests several indicators of work stress:

a. Workload. The burden of employees who must be completed according to the time that has been borne, employees will experience work stress if the workload given is excessive.

b. Leadership Attitude. The attitude of superiors to their subordinates must be firm. Firm is different from firm, superiors must be firm, among others, in giving orders and decisions. An attitude of communication and openness is also very important and can bring the relationship between superiors and subordinates closer.

c. Work Equipment. Tools to do work and make it easier for us to carry out tasks.

d. Working Environment Conditions. If the conditions in which we work are good and comfortable, the situation at work is also pleasant.

e. A Job and Career. Career development and progress in one's work, so that one has the appropriate position in the company.

\section{Definition of Work Ability}

Irawan (Amelia Rahmi et all, 2017) is a state of work ability in employees who work sincerely and successfully according to their field of work. While Logor (2015: 3) ability is the expertise of an individual in mastering his skills such as his job. It can be concluded that ability is very important in the world of work, a person must have expertise and be able to master his work to make it easier to do his job. Today's ability is very important 
because now companies are looking for workers who have many skills in various fields. It would be nice before applying for a job we have to hone and prepare the skills we have.

\section{Work Ability Indicators}

Irawan (Amelia Rahmi et all, 2017) suggests several indicators of work ability are:

a. Work performance. Work results per certain period, such as targets, standards that have been mutually agreed upon.

b. Education. The actions of employees in mastering knowledge that will result in changes in work.

c. Skills. Skills are a person's basic abilities that can be developed by learning and continuing to be honed. Along with that someone becomes an expert in the field.

d. Attitude. Employee's behaviour, namely by showing a good work ethic, being able to cooperate with existing organizations in the company, employees must be honest in doing their jobs in order to gain the trust of superiors.

e. Knowledge. The understanding and potential of the employee in the company.

\section{Hypothesis}

Temporary answer to the formulation of the problem which in the chapter above is determined based on the theoretical basis and the conclusions of relevant previous research, so that the following hypothesis can be established:

First Hypothesis: It is stated that training has an effect on work performance so that employees must have good performance so that employees can get achievement employment

Second Hypothesis: it was stated that Job stress Job Performance Against Influential, this shows that when employees experience stress will decrease the employee's job performance.

Third Hypothesis: It is stated that work ability has an effect on work performance if employees have more abilities, they will certainly get work performance from the company.

\section{RESEARCH METHOD}

To find out the research design in this study, the authors make a research design that aims to simplify, and be able to understand how the influence between the independent variables (independent variables) on the dependent variable (related variables) of the design is as follows:

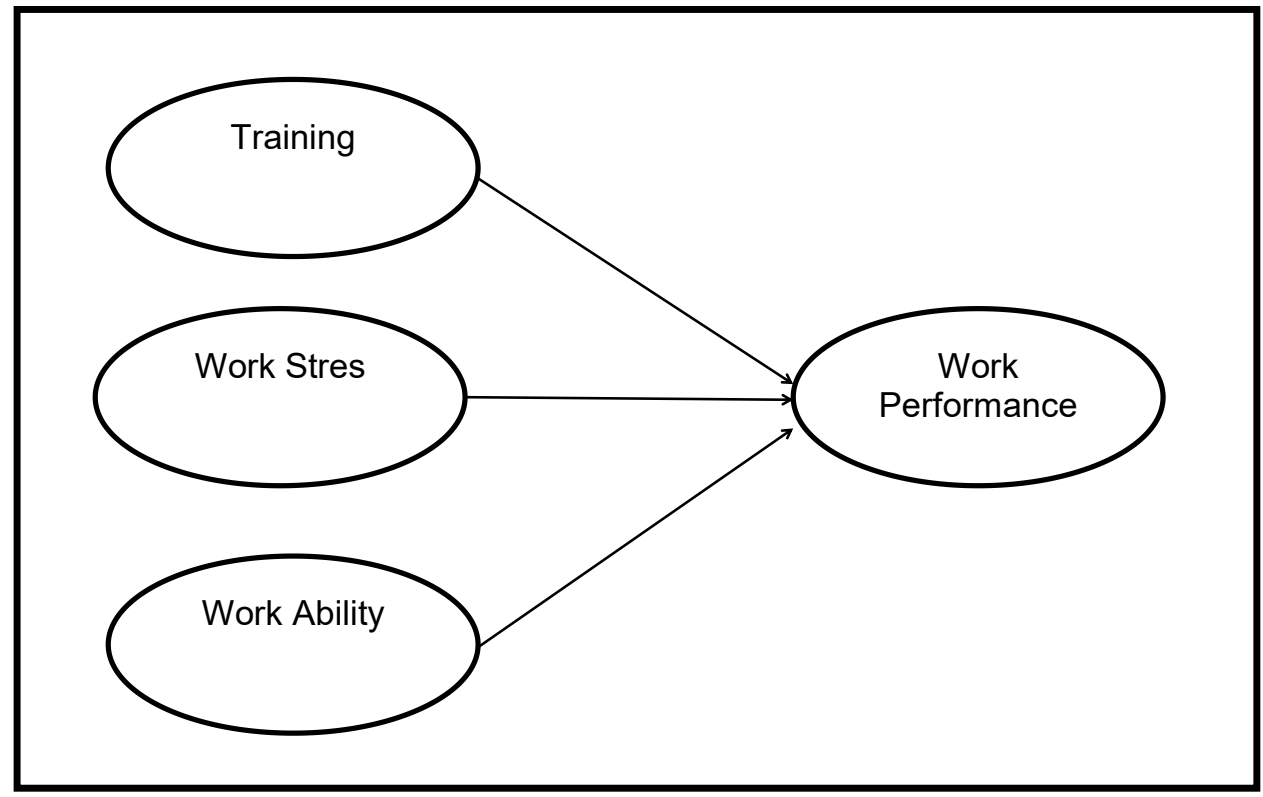

Figure 1

Research Design

Fitri Rezeki; Rahmat Hidayat. The Effect of Training, Work Stress and Work Ability on Work Performance PT Mukti Mandiri Lestari 
In this review, the creators used quantitative exploration. According to the hypothesis (Sugiyono, 2013) quantitative is a clear technique because it relies on positivism. This strategy is used to analyze a particular population or test. Inspection procedures are generally carried out arbitrarily. A variety of information using quantitative/measured examination instruments which are entirely aimed at testing the set-up theory. This technique is known as an appropriate quantitative strategy (Sugiyono, 2013) quantitative research is a number or numbers that can be determined efficiently and in this review using a measurable recipe.

The area or spot in this exploration was carried out at PT Mukti Mandiri Lestari and directed observation checks began in September 2020, the reason for paying attention to this inspection spot is to see what miracles or problems are happening at PT Mukti Mandiri Lestari.

The population is a speculative area consisting of items or articles that have certain characteristics and qualities that are controlled by analysts to concentrate and then draw conclusions (Sugiyono, 2013). The population in this exam is all representatives of PT. Mukti Mandiri Lestari.

According to (Sugiyono, 2013), "Exemplary is very important for the number and character that is driven by the community". The strategy used in this review is the embedded test procedure or statistical method that should be used. According to (Sugiyono, 2013) irregular examination is a testing method in which all people in the population either separately or together are offered the same opportunity to be selected as test individuals. In this review, the creators have a population of 70 individuals, so from that number, 58 individuals were taken as a test. From table 3.2 above, it is known that the population of PT. Mukti Mandiri Lestari totaled 70 employees, so the number of samples used was 59 employees.

According to the table above, the results of the calculation of the validity of the Work Stress variable (X2) are known that the value of rCount > rTable, the questionnaire items submitted are valid and feasible to use.

Reliability tests were carried out on questions in the questionnaire which were declared valid. A variable was said to be reliable if the answers to the questions were always straight and consistent. The reliability coefficient of the instrument aims to see the consistency of the answers to the questions given by the respondents, then the reliability is calculated using the "Cronbach's Alpha" formula. The calculations were carried out with the help of the SPSS computer program.

\section{Classic Assumption Test Normality Test}

Ordinarity test serves to test information under normal circumstances or not. Ordinary and good information is information whose results are positive or commonly referred to as being conveyed. The regularity test strategy that can be used to test residual alienation is Kolmogorov-Sminov (KS).

Table 2 Normality Test Results

One-Sample Kolmogorov-Smirnov Test

\begin{tabular}{|ll|r|}
\hline N & \multicolumn{1}{|c|}{$\begin{array}{c}\text { Unstandardized } \\
\text { Residual }\end{array}$} \\
\hline $\begin{array}{c}\text { Normal } \\
\text { Parameters }{ }^{\mathrm{a}, \mathrm{b}}\end{array}$ & Mean & 59 \\
& Std. & .0000000 \\
Most Extreme & Deviation & 2.84833134 \\
Differences & Absolute & .108 \\
& Positive & .075 \\
Statistic Test & Negative & -.108 \\
& & .108 \\
\hline
\end{tabular}

Fitri Rezeki; Rahmat Hidayat. The Effect of Training, Work Stress and Work Abilityon Work 


$$
\begin{array}{l|l}
\text { tailed) } & \text { Asymp. Sig. (2- } \\
\hline
\end{array}
$$

From the table above, it can be seen that the value generated in Asym.sig is 0.086 which can be said that the asymp.sig value of 0.086 is more prominent than 0.050 , so it can be said that the information is usually disseminated, and based on Figure 4.4 the P-plot diagram test above, quite possibly seen that the focus spreads. around the slash and its spread follows the slash. So it can be assumed that all the factors of Exercise, Job Stress and Work Ability are practical, because they meet the needs of ordinary assumptions using the P-plot relapse model.

\section{Hypothesis Test \\ Multiple Linear Regression Analysis}

Table 3 Multiple Linear Regression Analysis Results Coefficients $^{a}$

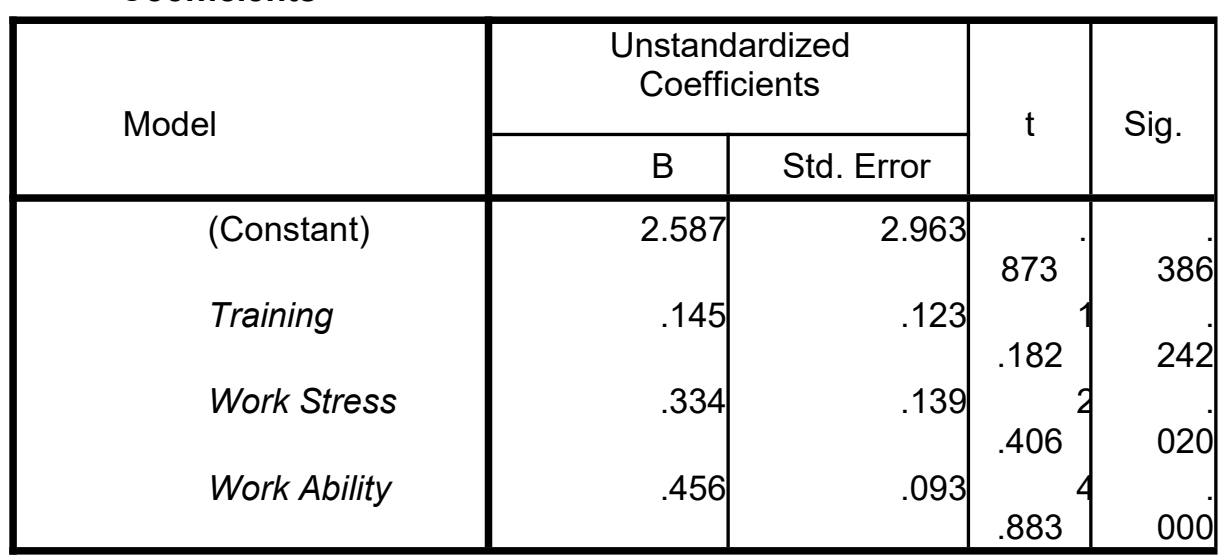

a. Dependent Variable: Work Performance

According to the information above, as a result of the various direct recurrence examinations above, the following conditions were obtained:

$Y=a+b 1 X 1+b 2 \times 2+b 3 X 3++e Y=2.587+0.334 \times 1+0.456 \times 2$

Data:

$\mathrm{Y}=$ Subordinate Variables $\mathrm{X} 1 \mathrm{X} 2 \mathrm{X} 3=$ Free factor $\mathrm{a}=$ Stable

$b 1+b 2+b 3=$ Coefficient

The clarifications of the various coefficient conditions are as follows:

1. A fixed value of 2.587 indicates that the factors of Preparation, Work Pressure and Work Capacity are considered consistent or worth $X=0$ then it tends to be judged that the Work Implementation Value is 2.587

2. The variable coefficient $(X 1)$ is 0.145 , the value of the Preparation variable shows that one respondent increases and others remain. then, at that time, it can be very well assessed that the value of the Preparation variable is 0.145

3. The coefficient of the variable work pressure or stress X2) is 0.334 . The value of the Work Pressure variable shows that the Work Quality variable increases by 1 respondent and the others are consistent, it tends to be assessed that the value of the Work Pressure variable is 0.334 .

Fitri Rezeki; Rahmat Hidayat. The Effect of Training, Work Stress and Work Ability on Work Performance PT Mukti Mandiri Lestari 
4. The coefficient of Work Capacity variable $(X 3)$ is 0.456 the value of the Work Capacity variable shows that the Work Capacity variable increases by 1 respondent and the others are consistent, so it tends to be judged that the Work Capacity variable is worth 0.456 .

\section{t Test (Partial)}

Fractional Test is used to dissect the importance value of each autonomous variable, especially Preparation, Work Pressure and Work Capacity, which can have a half-way (discrete) impact on the dependent variable, especially Work Implementation. The dynamic rules for the t-test are:

1. if $\mathrm{t}$ count $>\mathrm{t}$ table, and sig. $<0.05$ then $\mathrm{Ho}$ is rejected and $\mathrm{Ha}$ is recognized

2. in terms of $\mathrm{t}$ count $<\mathrm{t}$ table, and sig $>0.05 \mathrm{Ho}$ is recognized or $\mathrm{Ha}$ is rejected

3. determine $t$ table at an importance level of 0.05 with a two-tailed test with data $\mathrm{df}=\mathrm{nk}-1$ :

$n=$ Number of test

$k=$ Number of autonomous factors

$\mathrm{df}=59-3-1=55$ then obtained $\mathrm{t}$ table equal to 2,00

Table 4 t-test analysis results Coefficients $^{\mathrm{a}}$

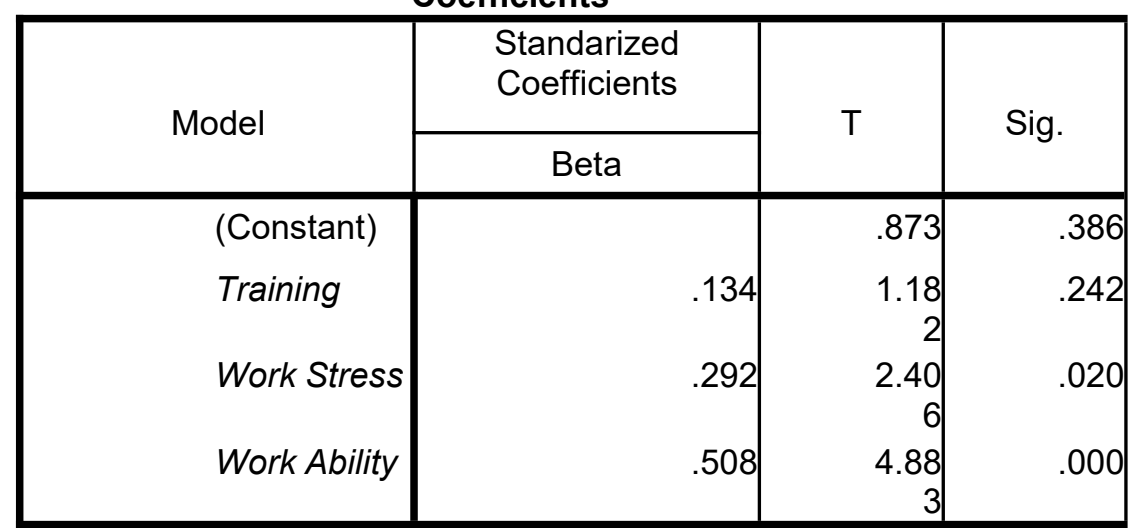

a. Dependent Variable: Work Performance follows:

Looking at table 4 . above, the conversation for the consequences of the t-test is as

1. Impact (X1) on Work Implementation ( $\mathrm{Y}$ Depending on the results of incomplete calculations, preparation has an importance value of 0.242 and a positive relapse coefficient of 0.134 while the t-count value obtained is 1.182 smaller than the ttable value of 2.00 Depending on these results, the theory stating "there is no favourable outcome halfway between the independent factor Prepare (X1) and the dependent variable Work Execution $(Y)$ " was declared dismissed.

2. Effect of Work Pressure (X2) on Work Implementation ( $Y$ ) Judging from the computational results of fractions, Work Pressure has an importance value of 0.020 and a positive relapse coefficient of 0.292 while the t-count value obtained is 2.406 which is more prominent than the t table, namely 2, 00 . Given these results, the theory states "there is a favourable halfway result between the independent factor Work Pressure (X2) and the dependent variable Work Performance $(Y)$ " then, at that point, is otherwise recognized.

3. Influence of Work Capacity or Ability (X3) on Work Implementation (Y) Judging from the results of the fractional calculation, work capacity is important 0.00 and the relapse coefficient is positive 0.508 while the t-count value obtained is 4.883 which is more prominent than $t$ table, which is 2.00 . In view of these results, the theory states that "there is an incomplete constructive result between the independent factor of Work Capacity (X3) and the dependent variable of Work

Fitri Rezeki; Rahmat Hidayat. The Effect of Training, Work Stress and Work Abilityon Work 
Performance $(\mathrm{Y})$ " then, at that point, is declared to be recognized.

\section{Discussion}

After testing the instrument and analyzing the data described previously, it can be explained in the discussion about the Effect of Training, Work Stress and Work Ability on the Work Performance of PT. Mukti Mandiri Lestari is in the information below:

1. Legitimacy test

The legitimacy test is carried out by comparing $r$ juggling numbers and $r$ tables, while to get a very good $r$ table, it can be obtained with the second $r$ table item, namely determining Alpha $=0.05$ Then $n$ (test) $=59$ individuals so that the value of $r$ table results can be obtained by using the equation $\mathrm{df}=59-2=57$ which is 0.322 . Judging from the legitimacy test above, it tends to be seen that all assertion instruments on the factors of Preparation, Work Pressure and Work Capacity are announced substantially and can be utilized.

2. Dependency test

The dependency test in this review uses a cut-off score of 0.60 with Cronbach's Alpha prescription to decide that all instruments in the factors of Preparation, Work Pressure and Work Capacity have Cronbach's Alpha quality above 0.60 . So, this shows that all explanations can be solidly announced.

3. Normal test

According to the information above, it can be seen the value of Asymp. This means that 0.200 is more than 0.050 then the recurrence model information is spread regularly.

4. Multicollinearity test

The resilience value of the three factors of Preparation, Work Pressure and Work Capacity is more considered than 0.10 so that multicorneality does not occur. Furthermore, judging from the measured VIF value, the three factors whose FIV value is below 10.0 then do not occur multicorneality.

5. Heteroscedasticity test

As a result of the above heteroscedasticity test based on the realistic description of the Scatterplot, it shows that the relapse model does not have heteroscedasticity manifestations. Based on the focus that is spread above and below the 0 on the $Y$ hub and does not form a specific example. So, it tends to be assumed that this relapse model does not occur heteroscedasticity.

6. Coefficient

The plan to measure how far the use of the dependent variable, the side effect of the assurance coefficient (R2) above shows an adjusted R-square value of 0.718 . This shows that autonomous factors such as Preparation, Work Pressure and Work Capacity can clarify the dependent variable.

7. Regression test

Each independent factor, especially Preparation, Working Pressure and Working Capacity, has a fixed quality, with the value of the Preparation variable (X1) of 0.145 , the Working Pressure variable (X2) of 0.334 and the Working Capacity variable $(\mathrm{X} 3)$ of 0.456 .

8. $\quad t$ test

According to the information above, the preparation factors and worker attributes declared are not important because the t-count value is lower than the t-table. The $\mathrm{t}$-table value in this review is added up to 2.00 , the $\mathrm{t}$-count value of the Preparation variable is 1.182 , the Working Pressure variable is 2.406 and the Working Capacity variable is declared critical on the grounds that the t-count is more prominent than the t-table of 4.883 .

\section{CONCLUSIONS AND SUGGESTIONS}

\section{Conclusions}

According to the investigation and discussion above as well as the reasons for this

Fitri Rezeki; Rahmat Hidayat. The Effect of Training, Work Stress and Work Ability on Work Performance PT Mukti Mandiri Lestari 
review, in particular to decide the impact of Preparation, Work Pressure and Work Capacity at PT Mukti Mandiri Lestari, are as follows:

1. After confirming the incomplete test using the t-test, the results show that there is no critical influence halfway between training on Job Implementation. From the results of the incomplete $t$ test that is equal to 1.265. However, this value can still be ascertained because $t$ count $<t$ table is $1.182<2.00$. These results are obtained from respondents with 8 proclamations that have been tried for legitimacy, dependence and mediocrity.

2. The results of the review show that work pressure is something that has less impact on the implementation of work. From the results of the t test or the incomplete value of the Working Pressure variable, it is 2.406 . Where it has been stated that work pressure has a positive effect on the work implementation of PT Mukti Mandiri Lestari, on the grounds that $t$ count $>t$ table is $2,406>2.00$. These results are obtained from respondents' answers with 8 explanations that have been tried for legitimacy, unshakable quality and reasonableness.

3. A large and appropriate work capacity as well as meeting support will affect Work Implementation at PT Mukti Mandiri Lestari, where from the results of testing using $t$ or incomplete investigations showing an effect of 4,883 From these results it is stated that Work Capacity has a positive effect on the Work Implementation of PT Mukti Mandiri Lestari remembers $t$ arithmetic $>t$ table, which is $4883>1.985$. These results were obtained from respondents with 8 articulations and have been tested for legitimacy, dependability and mediocrity.

\section{Suggestions}

After this research and seeing the conclusions that have been made above, the researchers provide some suggestions for the readers of this paper as follows:

1. From the results of the analysis of the Training variable on Work Performance, it is known that the Training at PT. Mukti Mandiri Lestari partially positive effect on Work Performance $(y)$. Even so, the training in this company needs to be considered and improved because the $t$ value or partial to Work Performance in this company needs to be considered and improved because the $t$ or partial value is the lowest compared to the variables (X2) and (X3), this value will be even higher if the company can improve training so that employees can be more active at work.

2. From the results of the Work Stress variable analysis, it is found that Work Performance has the highest $t$ test value, if employees have stress at work, employees will continue to be lazy in doing work.

3. The results of the study of the Work Ability variable also have a positive effect on the Work Performance of PT. Mukti Mandiri Lestari, it is hoped that the things that need to be maintained and considered are the workload in accordance with existing policies in the company.

\section{REFERENCES}

Haryono, S., Supardi, S., \& Udin, U. (2020). The Effect Of Training And Job Promotion On Work Motivation And Its Implications On Job Performance: Evidence From Indonesia. Management Science Letters, 10(9), 2107-2112. https://doi.org/10.5267/j.msl.2020.1.019

Hutahaean, H. (2020). Pengaruh Kompetensi Dan Pelatihan Terhadap Prestasi Kerja Pegawai Pt. Sinar Deli Medan. Journal IImiah Simantek, 4(3), 1-9.

Poluakan, biily christovel, Tumbuan, W., \& Trang, I. (2017). Issn 2303-1174. 5(2), 388-398.

Fitri Rezeki; Rahmat Hidayat. The Effect of Training, Work Stress and Work Abilityon Work 
Rahmi, A., \& Aziz, A. (2017). Pengaruh Disiplin Kerja, Pelatihan Kerja Dan Kemampuan Kerja Terhadap Prestasi Kerja Pegawai Biro Umum Kantor Gubernur Provinsi Aceh. Jurnal Bisnis Administrasi, 06(02), 24-31.

Riyadi, Slamet. (2011). Pengaruh Kompensasi Finansial,Gaya Kepemimpinan, dan Moti vasi Kerja Terhadap Kinerja Karyawan pada Kantor Manufaktur di Jawa Timur. Jurnal Manajemen dan Kewira usahaan Vol. 13 No 1 Maret 2011 : 4045.Tanggal akses 28 Oktober 2016. http://cpanel.petra.ac.id/ejournal/index.ph $\mathrm{p} / \mathrm{man} /$ article/viewArticle/18243

Sugiyono. (2013) Metode Penelitian Kuantitatif (Ke-19). Cv. Alfabet.

Sugiyono. (2012) Metode Penelitian Kuantitatif Kualitatif dan R\&D. Bandung

Suhendar, H. (2016). Pengaruh Kemampuan Dan Loyalitas Kerja Terhadap Prestasi Kerja Pegawai Di Kantor Kelurahan Kebon Bawang Di Jakarta Utara. The Indonesian Journal Of Public Administration (IJPA), 2(2), 50-64. Https://Doi.Org/10.52447/ljpa.V2i2.511

Sulistiyani, M., Widiana, M. E., \& Sutopo. (2017). Pengaruh Stres Kerja, Konflik Kerja Dan Kepuasan Kerja Terhadap Prestasi Kerja Karyawan Pada Pt. Japfa Comfeed Indonesia Tbk. Wonoayu Sidoarjo. Manajemen Branchmark, 3(3), 335-347.

Sunarsi, D. (2019). Pengaruh Kompensasi, Komunikasi Dan Stress Kerja Terhadap Prestasi Kerja Karyawan Pada Pt Catur Putra Jaya Kota Depok - Jawa Barat. Jimf (Jurnal Ilmiah Manajemen Forkamma), 1(2), 113-127. https://doi.org/10.32493/frkm.v1i2.2543

Suwati Yuli. (2013) Pengaruh kompensasi dan motivasi kerja terhadap kinerja karyawan pada PT. Tunas hijau samarinda. Universitas Mulawarman. eJournal IImu Administrasi Bisnis, 2013 : hal 41-55 ejournal.adbisnis.fisip-unmul.org.

Suwatno dan Donni Priansa. (2011) Manajemen SDM dalam Organisasi Publik dan Bisnis. Penerbit Alfabeta. Bandung.

Wardana Surya Dendik (2013). Universitas Muhammadiyah Malang. Motivasi Berprestasi Dengan Kinerja Guru Yang Sudah Disertifikasi. Jurnal ilmiah psikologi terapan Vol. 01, No.01, Januari 2013 ISSN: 2301-8267.

Fitri Rezeki; Rahmat Hidayat. The Effect of Training, Work Stress and Work Ability on Work Performance PT Mukti Mandiri Lestari 
The Management Journal of BINANIAGA Vol. 06, No.02, December 2021 p-ISSN: $2527-4317$, e-ISSN: $2580-149 x$

$6^{\text {th }}$ Accreditation Rating: April 04, $2019-$ April 03, 2024

This Page intentionally be emptied

Fitri Rezeki; Rahmat Hidayat. The Effect of Training, Work Stress and Work Abilityon Work Page:256

Performance PT Mukti Mandiri Lestari 